\title{
PUSHING OR PULLING OF THE BUSINESS BY FAMILY MEMBERS: A STUDY OF FAMILY BUSINESSES IN SRI LANKA \\ Ravindra H. KURUPPUGE*, Aleš GREGAR
}

Tomas Bata University in Zlin, Faculty of Management and Economics, Czech Republic

*e-mail: kuruppuge@yahoo.com

\begin{abstract}
A number of family business researches affirm benefits of family involvement to the business while some of other studies assure only detriments of family involvement. When comparative studies of family businesses begin to surface on the family involvement in business, there is that irritating question on what effect is brought about by family involvement to the business. Therefore, the purpose of this study is to explore business advantages and disadvantages generated by family involvement in businesses in Sri Lanka. The present study attempted to address the above knowledge gap, using qualitative research approach and multiple case studies as the strategy of inquiry. Purposive sampling technique was used to select both cases and respondents. Privately held, successfully conducted four family businesses were selected as cases and, existing business owner and one family related manager from each case were taken as respondents. Data was collected mainly via semi-structured, in depth interviews, observations, and secondary documents. Data collection from interviews consisted of 15 interviews with 09 different people from four cases. Before the data analysis, coding and categorization of respondents' views from interviews helped to identify common patterns and themes from both within the case and across cases. The analysis was carried out in the light of Agency Theory and resulted in a rich understanding of business advantages and disadvantages of family involvement in businesses in Sri Lanka. The findings of this study indicated that the agency cost is created not only on business matters but also on family matters. Further, findings revealed that agency benefit also can be obtained by family business by handling the family matters carefully in line with business matters. Findings of this study clearly indicated that an extension to Agency Theory is required to explain owner agent relationship in family businesses.
\end{abstract}

Keywords: family business, family involvement, advantages (merit), disadvantages (demerit), agency theory and Sri Lanka.

\section{INTRODUCTION}

Families and businesses have always, to large extent, existed in a cycle and it has been argued that this cyclical existence has benefited both the family and businesses $[1,2]$. At the same time, some other researchers are also in a view that cyclical existence of families and business does not always provide benefits to the business [3]. Moreover after 1990s the field of family business emerged as a separate discipline and called for more research in the world [4]. Yet, no commonly agreed definition of family business can be found in family business literature either locally or globally. Different studies have defined family business differently in line with their study purposes. This study treats the family business as unique, inseparable, synergistic resources and capabilities arising from family involvement and interactions [5].

At the same time, the business world of Asia is strongly linked to family and family run businesses has been popular in many South Asian communities [6]. As a South Asian country, Sri Lankan indigenous management and business practices developed in a rich cultural heritage across 2500 years and has been take care of largely by teachings of the Buddha, a great philosopher and a social reformer [7]. Most of the studies about Sri Lankan businesses have concluded that traditional Sinhalese Buddhism bears some responsibility for retarding economic development through merit-making practices [8]. Over generations, these values have influenced the thinking and actions of the people and their participation in collective effort like performing businesses. This business life has been subjected to turbulent changes during the last couple of decades. However, because of the rich history and tradition of strong 
family ties, family businesses have long been considered as a part of the culture. Yet, the private sector of Sri Lanka has inherited its business tradition from mercantilist functions of the colonial private entrepreneur. They centered the business on three major plantation crops with a bias toward trade, commerce, and services [9]. Majority of such firms which were preliminary based on family ownership. Managerial positions were largely reserved for technically competent family members and the individual firms' behavior is largely influenced by families [10]. Accordingly, Sri Lankan business culture and its entrepreneurs have become largely family based and rooted predominantly in the merchant capitalist class [8].

Although family involvement in a firm distinguishes these firms from others, studies on the family involvement in businesses are limited and results are mixed. Especially very limited studies have been conducted to examine advantages and disadvantages of family involvement in businesses in Sri Lankan business context where all family firms are not alike as they vary significantly, among other aspects, in terms of the extent and mode of family involvement. Even though studies about family businesses generally emphasize the presence of the family in the business, those studies seem to be idle in reviewing the real impact created by family members to the business. At the same time, most renowned Agency theory, which explains owner-agent (manager) relation in business, seems to be not clearly explaining the owner-agent relation in family businesses. This knowledge gap has surfaced an irritating research question on family business, what and how real effect is brought about by family involvement in the business. In order to explore the phenomena in believing multiple realities in the world, instead of "what" and "why" research direction, the research problem of this study remains as, "how family members' involvement in business contributes to business functioning in family owned firms in Sri Lanka"?

\section{THEORETICAL BACKGROUND}

In order to maintain the theoretical rigor to explore the research problem, Agency Theory was employed as theoretical lens of this study. Agency theory main- ly discusses the relationship of business owner who invested money in the business and agent (manager) who serve for salary in the business on behalf of owner. The theory is further about intraorganizational processes from an economic perspective and it generally refers to the various ways that agents of a firm can influence the economic and noneconomic outcomes and behaviors of the firm [11, 12]. According to [11] and [13], Agency Theory refers to the conflicts of interest between an agent who act as a representative of a principal and owner of the principal.

The basic assumption underlying Agency Theory is that agents tend to be opportunists who, unless monitored effectively, will exploit owner-principals. It happens because of composition of a node of contracts. As a consequence, Agency Theory is applicable to all contractual relationships in the firm [14]. However, it focuses strongly on top managers because they are responsible for strategic level decision making [11]. At the same time, Agency Theory is based on fundamental of economics and its main behavioral assumptions reflects; (1) agents and principals (owners) are rational, (2) agents and principals are self-interested and (3) agents are more riskaverse than principals [11].

One of the main sub segments of this theory is agency cost. In business firms, shareholders mostly do not have time, interest, capacity or incentive to be involved in day-to-day management activities. As a consequence, shareholders (principals) delegate decision making to a smaller group, namely, management (agents). In one hand, this leads to opportunity costs, also called "agency costs" which concern the cost to the principals to monitor the behavior of an agent to minimize agent opportunism [15]. On the other hand, Agency Theory proposes that the contract between principal and agent is the main instrument for decreasing agency cost which would be named as agency benefit. This contract may include the development of a monitoring system to ensure that behaviors and outcomes do not deviate from the owners' interests. It might also include the establishment of an incentive system that intends to reward the agent for outcomes that are important to the principal (e.g., profitability, share price). 


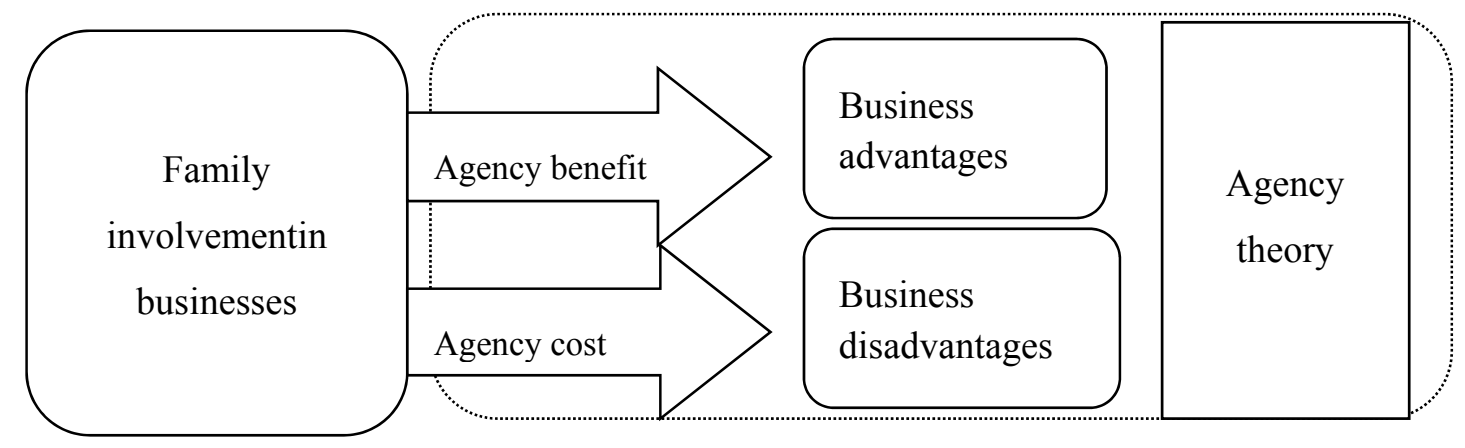

Figure 1. Concept Indicator Model

(source: Researcher's original construction)

Both agency cost and agency benefit in line with Agency Theory can be observed in family firms.

The researcher of this study attempts to develop an extension to Agency Theory through the agency benefit and agency cost. Even though Agency Theory explains owner and agent relationship of a business, owner and agent becomes one person in most cases of family businesses. At least, agent/s become/s very close relatives to owner/s. In this situation, both owners and managers of family business would try to optimize one objective in the business rather than optimizing their own different objectives as owners and managers. As Agency Theory does not provide enough explanation about owner agent relationship of family business and, family and nonfamily businesses are significant different to each other in case of owner agent relationship, the researcher of this study deserve to bring up enough evidences to prove that a new framework / extension of Agency Theory is required to explain the owner agent relationship of family firms.

Based on the literature and theoretical reviews, following concept indicator model (Fig. 1) was developed by the researcher.

\section{Objectives and methodology}

\section{- Objectives / aim of the study}

The main objective of this study is to seek the possibility to extend the Agency Theory explaining owner agent relationship in family firms clearly as family businesses are relatively different to non-family businesses. At the same time, owner agent relationship in family businesses also significantly differs from other non-family businesses [11]. Accordingly, main objective of this study is achieved through analyzing business advantages and disadvantages of family involvement in family business. At the same time, as sub-objective, this study explores how business advantages and disadvantages are generated by family involvement in family businesses. Business advantages and disadvantages generated by family members were identified through agency benefit and agency cost.

\section{- Methodology of the study}

In the process of exploring business advantages and disadvantages of family involvement in businesses, the methodological stance for this research remained in qualitative believing multiple realities in the world. The researcher carried forward the research within interprevistic paradigm believing that reality is subjective and it is mentally constructed by individuals [16]. In order to understand the complex phenomena business advantages and disadvantages of family involvement in business which is very significant to the context of the business, the case study method was executed for this research.

At the same time, the merit and demerit of involvement in business by family members differ from context to context in various aspects and it would not be generalized at any point. Because of this, understanding the reality of generating merit and demerit of business by family involvement in business, considering the features in family business over non family business, the multiple case study approach was used. It permitted the researcher to strive towards understanding the phenomenon of interest by using several independent instrumental case studies 
to get an insight into the study area. Purposive sampling was used to select both cases and respondents. Privately held, successfully progressive 04 family businesses which of each firm has at least 25 years of business history were selected as cases. These selected family businesses are located in three different districts in Sri Lanka. From each case, existing business owner and one family related manager who has at least 05 years of experience in the business were considered as respondents.

Data was collected mainly via semi-structured, in depth interviews, observations, and secondary documents such as minutes of meetings and annual reports of selected family firms. At the primary data collection, interview guide was partially modified during the different rounds of data collection to better reflect the emerging themes. Interviews were conducted during the period of January to April 2013. Data collection from interviews consisted of 15 interviews with 09 different respondents from four cases. Some of the respondents were interviewed four times in the interview process. The summary of interviews is shown by Table 1 .

All the interviews were recorded and then transcribed. Eleven out of fifteen interviews were conducted in English. The rest was conducted in their mother tongue (Sinhala) and translated into English by the researcher.

Table 1. Distribution of interviews by case and type of interviewee (source: researcher's original construction)

\begin{tabular}{|l|c|c|c|c|c|c|c|c|c|c|c|}
\hline \multirow{2}{*}{ Item } & \multicolumn{2}{c|}{ Case 1 } & \multicolumn{3}{c|}{ Case 2 } & \multicolumn{2}{c|}{ Case 3 } & \multicolumn{2}{c|}{ Case 4 } & \multicolumn{3}{c|}{ Total } \\
& A & B & A & B & A & B & A & B & A & B \\
\hline A family executive/s & 1 & 2 & 1 & 2 & 1 & 2 & 2 & 4 & 5 & 10 \\
\hline Current owner/founder & 1 & 1 & 1 & 1 & 1 & 1 & 1 & 2 & 4 & 5 \\
\hline Total & 2 & 3 & 2 & 3 & 2 & 3 & 3 & 6 & 9 & 15 \\
\hline
\end{tabular}

Notes: "A" denotes no. of interviewees and "B" denotes no. of interviews

Table 2. Main characteristics of respondents

(source: researcher's original construction)

\begin{tabular}{|c|c|c|c|}
\hline Name & $\begin{array}{c}\text { Case } \\
\text { and status }\end{array}$ & Basic characteristics & Industry \\
\hline Mr. Nishan & case 01 , owner & $\begin{array}{l}\text { age } 45,16 \text { years' experience } \\
\text { in the business, an engineer }\end{array}$ & machinery production and sales \\
\hline Ms. Iresha & case 01 , senior manager & $\begin{array}{l}\text { age } 43,14 \text { years' experience } \\
\text { in the business }\end{array}$ & machinery production and sales \\
\hline Mr. Pradeep & case 02 , owner & $\begin{array}{l}\text { age } 53,20 \text { years' experience } \\
\text { in the business, specialist in eye } \\
\text { care }\end{array}$ & optical and eye care \\
\hline Ms. Kumari & case 02 , manager & $\begin{array}{l}\text { age } 49,15 \text { years' experience } \\
\text { in the business }\end{array}$ & optical and eye care \\
\hline Mr. Sunil & case 02 , manager & $\begin{array}{l}\text { age } 35,15 \text { years' experience } \\
\text { in the business }\end{array}$ & optical and eye care \\
\hline Mr. Vijitha & case 03 , owner & $\begin{array}{l}\text { age } 60,40 \text { years' experience } \\
\text { in the business }\end{array}$ & furniture production and sales \\
\hline Mr. Shantha & case 03 , owner & $\begin{array}{l}\text { age } 57,35 \text { years' experience } \\
\text { in the business }\end{array}$ & furniture production and sales \\
\hline $\begin{array}{l}\text { Ms. Wimalawa- } \\
\text { thie }\end{array}$ & case 04 , senior owner & $\begin{array}{l}\text { age } 65,42 \text { years' experience } \\
\text { in the business }\end{array}$ & foods and restaurant \\
\hline Mr. Ramesh & case 04 , senior manager & $\begin{array}{l}\text { age } 43,12 \text { years' experience } \\
\text { in the business }\end{array}$ & foods and restaurant \\
\hline
\end{tabular}


Before the data analysis, coding and categorization of respondents' views from interviews helped to identify common patterns and themes from both within-case and across-case analyses. While the main data analysis strategy was pattern matching, the unit of analysis of the study was a single case. The analysis was carried out in the light of Agency Theory and resulted in a rich understanding of nature of family involvement in businesses in Sri Lanka. The quality of the research was maintained by demonstrating internal and external validity of the study.

\section{$4 \quad$ Results and discussion}

This analysis of how family involvement brings advantages and disadvantages to business become more valid as it is usually expected that family members have more freedom to intervene in business issues than intervening of non-family members. This freedom may lead to the abuse of the business by family members and even if the family members show goodwill in their actions, the business may be worse off. As shown in Table 1 above, background information in details of respondents of interviews can be summarized as shown in Table 2 below. The emerged concepts in relation to family involvement consequences; advantages or disadvantages of business are identified based on answers provided by these respondents in interviews.

\section{- Family involvement and business: advantages}

At the beginning of the analysis of how business advantages are created by family involvement, it is important to note the researcher observation in the interview process. The researcher experienced that respondents of cases were reluctant to express their ideas directly. Either family involvement could be advantageous or disadvantageous to their business, respondents (both managers and owners) wanted to show their togetherness and business success which was tightened by family involvement. As business advantages created by family involvement were identified through the agency benefits, respondents' exaggeration reflected minimum in the analysis.
Few of respondent's quotations in interviews with reference to business advantages created by family involvement can be shown as below.

- "As top managers of the business, my brothers and I have a great responsibility. We always work together in order to achieve business objectives. We discuss business matters even when we meet at social functions. Always, no business secretes are kept amongst us and trust is the key for us to take the business forward." (Case 02, respondent 01).

- "Commitment is the fundamental factor to make a business successful. Dedication and genuine presence in the business is also required. If somebody does not have ownership of business and if he works for salary, he does not need to see business development. He wants only salary at the end of the month." (Case 01, respondent 01).

- "The advantage of employing family members in the business is developing understanding or rather mutual understanding." (Case 04, respondent 02).

- "When it comes to my husband, he started right from the bottom. Even when he was a small child he used to come here and see this environment. His father has always encouraged him to familiarize with this environment when he was of Montessori age. He was very rarely away from this business and this business now has become an intrinsic part of his life. He spent only a very less time at home with us." (Case 01, respondent 02).

In the analysis of business advantages generated by family involvement in family businesses in Sri Lanka, the results show that agency benefits of family involvement under categories of aligning principal agent goals and sharing values among family members. It proves that family managers and executives aspire for higher purposes in their jobs in case of better business performance as they are not mere employees in the business. They often act unselfishly for the benefit of the organization [5]. The following categorization of respondent views (Fig. 2) indicates how business advantages are created by family involvement in family business in a situation where family members perform as managers and owners of the business. The main theme emerged in the analysis is, family members are intrinsically motivated by higher level needs to act for the collective work of their firms. They identify with the organization and embrace its objectives as their own objectives. They are committed to make it succeed, even to the extent of personal sacrifice. 


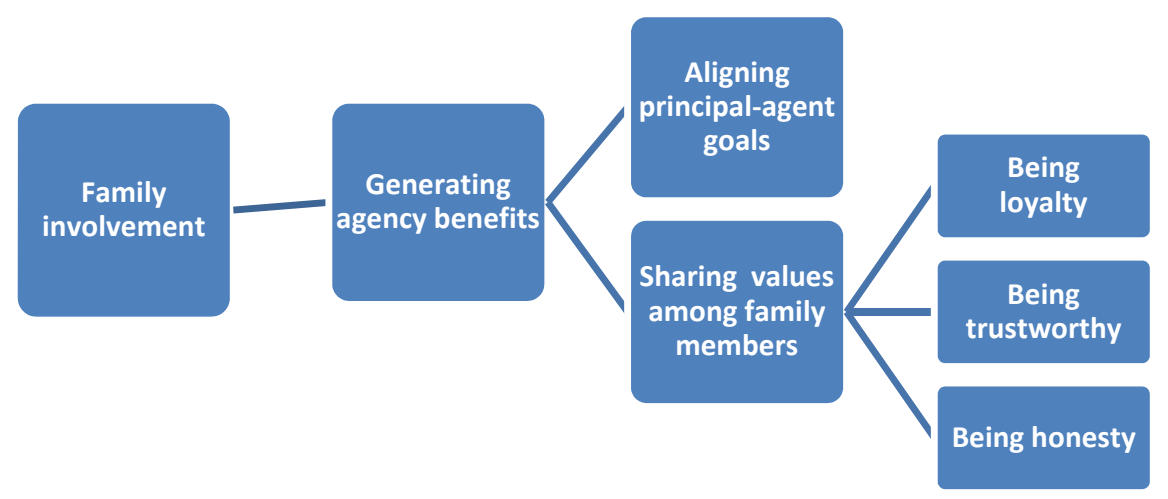

Figure 2. Categorization of views of respondents for business advantages (source: researcher's original construction)

These attitudes would be especially prevalent among family businesses in which leaders / managers are either family members or emotionally linked with the family. Such executives often commit deeply to the mission of the business and omit personal temporary benefits. They become treasure to its employees and stakeholders, and feel motivated to do their best for the owning family and the organization collectively [17]. But according to respondent's views, it could be that not all kinds of family businesses are likely to breed such relationship in owners or their agents. Despite advantages, the analysis views about some disadvantages (demerit) of having family members in the family businesses as well.

\section{- Family involvement and business: disad- vantages}

Family involvement in the business becomes a two sided coin which consist of both advantages and disadvantages [3]. In the analysis of how family involvement generates business disadvantages to family business can be looked through agency cost. According to respondents, especially after the founder hands over control of the business to his or her followers, quarrels among siblings or cousins can interfere. Those concerns of the business normally become agency cost for the business as family members are still strong enough to make better issues than non-family members. Some of the quotations provided by respondents in the interview process can be shown below.

- "We can't exactly say that family involvement always creates advantages to the business. It depends on their positions, education, attitudes and etc. Sometimes, the company can incur huge losses be- cause of unnecessary family member interferences." (Case 02, respondent 02).

- "My husband's father and his brothers managed group of this business. His brothers had left this firm after getting their share. It means that the company has been divided among brothers. That was about few years ago and because of that our finances are limited." (Case 04, respondent 01).

- "I travel to a foreign country at least once in six months. Whatever situation is in the business, it is not a great concern." (Case 03, respondent 02).

- "Our main target is to carry forward this business in this competitive environment because, people know us only through this business and we got this from our father." (Case 03, respondent 01.)

Disadvantages of family involvement are concerned under the categories of failure in monitoring family members and emerging complicating goals in the family. More than anything, the motive of the family member who is engaged in the business is a great concern. According to the respondents' view, the interplay between the family and the business may become critical in some situations when family members much affiliated to the business. Conditions that may intensify problems like role ambiguity, communication difficulties among family members, and business decisions which negatively affect families. According to the agency theory, monitoring activities needed to manage agency cost. Agency costs arise when the interest of the managers are not aligned with that of owners and take form of preference for the job perks, shrinking, and making selfcentered and entrenched decisions that reduce the shareholder wealth [5]. Ultimately, respondents' views of making business disadvantages by family involvement can be summarized as Fig. 3 below. 


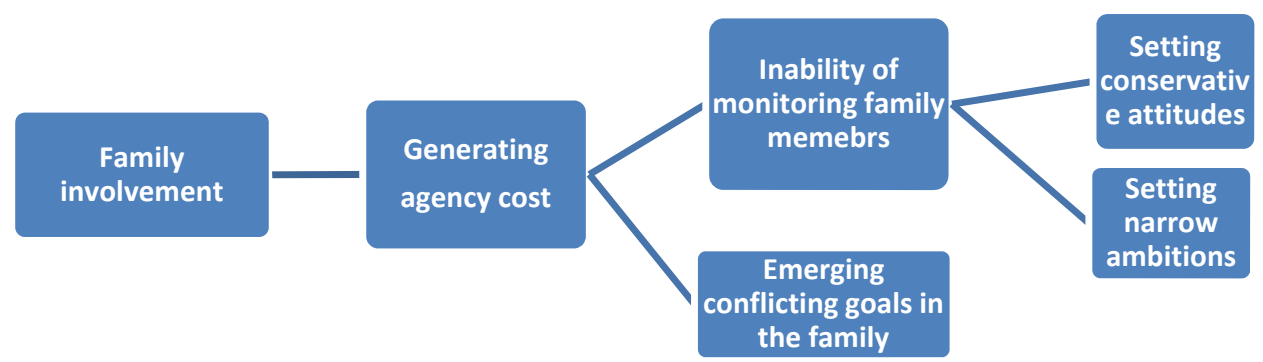

Figure 3. Categorization of views of respondents for business disadvantages (source: researcher's original construction)

\section{- Family involvement and business: advantages and disadvantages}

In the analysis, business advantages of family involvement are identified through the sub categories of the alignment of the principle - agent goal and shared values among family members. Business disadvantages of family involvement are identified through the sub categories of failure in monitoring and conflicting goals in the family. At the end of the analysis, in case of answering the main research problem of this study, the way that both advantages and disadvantages creation by family involvement reflect by following Fig. 4. This result is shown as per respondents' views in interviews of family involvement in their businesses.

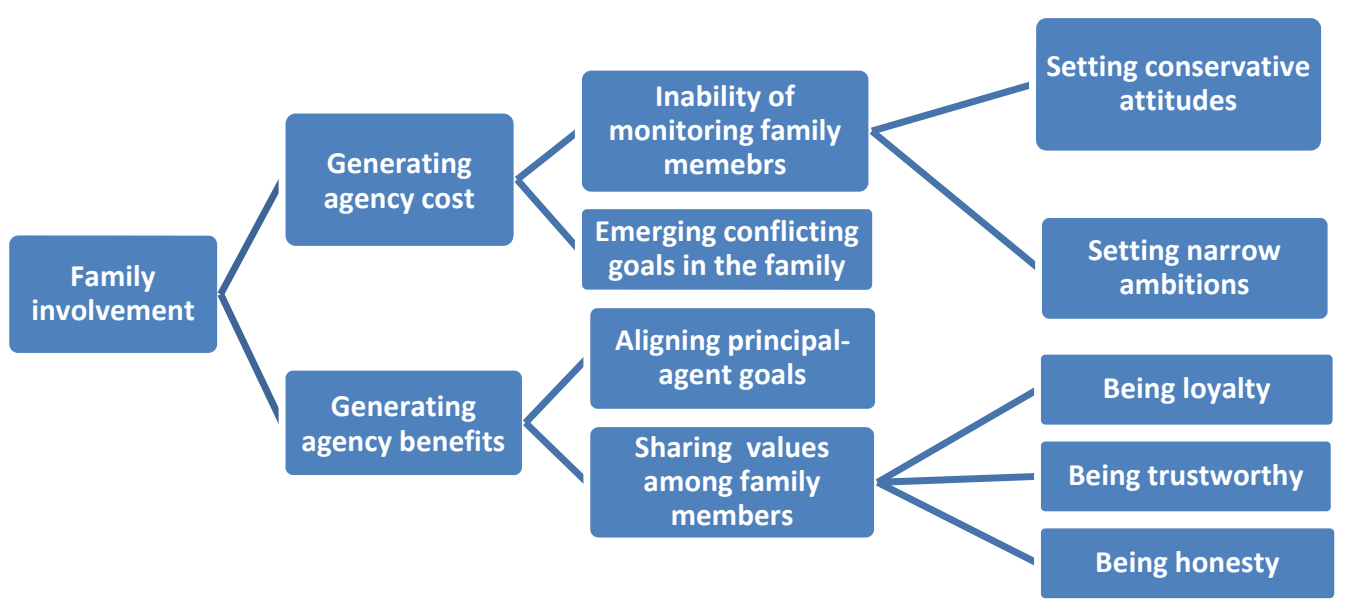

Figure 4. Business advantages and disadvantages created by family involvement in businesses in Sri Lanka (source: researcher's original construction)

By looking in details about business advantages and disadvantages of each category of the analysis, some interesting themes related to family involvement emerged when research question is looked through Agency Theory. One of the emerging insider themes which can be considered as a key finding of this study is that agency cost is created not simply because of business matters but because of family matters. At the same time, the management/governance of the family business is not based on contemporary management/governance practices and they are more connected to family relation. Agency benefit also can be obtained by family business by handling the family matters carefully with business matters as family matters very closely related to business objec- tives. Some of agency benefits to the business by family managers are preoccupied by default. The whole analysis of business advantages and disadvantages of family involvement in business is compatible with one theme provided that the weight of these merits and demerits can vary sharply according to business type or industry. Both advantages and disadvantages generated by family involvement depend on the motive of individual family member. The broad term motive in this case can narrow down as business goal (common / family goal) and individual goal because for both goals, family members are motivated to be involved in business matters. The main theme that surfaced through this analysis is that when a family member who involves in the 
business having individual goals which deviate from the business goal results in demerit (agency cost) to the business. At the same time, when a family member involved in the business having business goals than individual goals result in merit (agency benefit) to the business. Based on above findings of this study it is clear that Agency Theory should be further expanded making reservations to explain owner agent relationship in family business.

\section{$5 \quad$ Conclusion}

Based on understanding of aim of this study, an expansion to Agency Theory is proposed as owner agent relationship of family business differs from other business. The evidences to prove the requirement of expansion to Agency Theory were identified mainly through business advantages and disadvantages of family involvement of the business. It was obvious in the study that some of the features of owner agent relationship of business remain unchanged for family business. Those features are well accommodated in Agency Theory as well. Yet, when owners and agents of a business optimize the same objectives in a business, the situation become insignificant to Agency Theory. It proves that family business makes the owner agent conflict of interest different to what really explained in Agency Theory. This finding signals that Agency Theory should be revisited to make an extension to accommodate owner agent relationship in family businesses. While theoretically revisiting of the Agency Theory is proposed, practically the results of this study would be useful for family business owners, managers and governors to take their business administration decisions different to non family businesses. Accordingly, the findings of the study will help family business managers to take their business related decisions effectively and efficiently.

\section{References}

[1] Morck R., Yeung B. - Family control and rent seeking society. Unpublished paper presented at the 2002, Theories of the Family Enterprise Conference, Wharton Business School, Philadelphia, PA. 2002.

[2] Narva R.L. - Heritage and tradition in family business: How family-controlled enterprises connect the experience of their past to the promise of their future [in] G.K. McCann, N. Upton (eds.) -
Destroying myths and creating vale in family business (pp. 29-38). Deland, FL: Stetson University, 2001.

[3] Chua J.H., Lloyd P., Steier L.P., Chrisman J.J. How family firms solve intra-family agency problems using interlocking directorates: an extension, Entrepreneurship Theory and Practice, 30(6), 777783, 2006.

[4] Dharmadasa P. - Family Ownership and Firm Performance: Further Evidence from Sri Lanka and Japan, International Journal of Asian Business and Information Management, 5(4), 34-47, 2014.

[5] Habbershon T.G., Mary L.W., Ian MacMillan. C. A unified systems perspective of family firm performance. Journal of Business Venturing, 18, 451465, 2003.

[6] Khana T., Yafeh Y., Business groups in emerging markets: paragons or parasites? Journal of Economic Literature, 45, 331-372, 2007.

[7] Ranasinghe S. - Managing in a Developing Context: Sri Lankan perspectives, E-Team Designs, Hokandara, Sri Lanka, 2011.

[8] Nanayakkara G. - Managing in Sri Lanka: Problems and Prospects, Volume II, Public Administration and National Development, Academy of Management Sciences, Colombo, Sri Lanka, 2004.

[9] Jayawardena K. - No bodies to some bodies: Rice of the colonial Bourgeoisie in Sri Lanka, Social Scientists' Association - Sri Lanka, Colombo, 2000.

[10] Nanayakkara G. - Culture and management in Sri Lanka, Postgraduate Institute of Management, University of Sri Jayawardenepura, Sri Lanka, 1992.

[11] Miller D., Sardais C. - Angel Agents: Agency Theory Reconsidered, Academy of Management Perspectives, 6-13, 2011.

[12] Fama E., Jensen M. - Separation of ownership and control. Journal of Law and Economics, 26, 301325, 1983.

[13] Eisenhardt K.M. - Building theories from case study research. Academy Management Review. 14, 532-550, 1989.

[14] Grabke-Rundell A., Gomez-Mejia L.R. - Power as a Determinant of Executive Compensation, Human Resource Management Review, 12, 3-23, 2002.

[15] Bainbridge S.M. - Executive Compensation: Who Decides?, Texas Law Review, 83, 1616-1662, 2005.

[16] Guba E.G., Lincoln Y.S. - Competing paradigms in qualitative research. In Handbook of qualitative research, Thousand Oaks, CA: SAGE Publications, Inc., 1994.

[17] Miller D., Isabelle L.B. - Managing for the long run: Lessons in competitive advantage from great family businesses. Boston, MA: Harvard Business School Press, 2005. 